\title{
Forming the digital environment for developing the electric power spatial infrastructure system of the region
}

\author{
Elena Shishkina ${ }^{1 *}$, Nadezhda Surnina ${ }^{1}$ \\ ${ }^{1}$ Ural State University of Economics, 8 Marta str. 62/45, 620144 Yekaterinburg, Russian Federation
}

\begin{abstract}
The study was carried out on forming the digital environment for developing the electric power spatial infrastructure system of the region. The system of documents aimed at forming and developing the digital economy and the digitalization of economic activity was analyzed. Target priorities of digitalization of spatial infrastructure systems of the region were determined. The article analyzes the dynamics in the use of information and communication technologies and global information networks by the organizations of the Sverdlovsk region. This dynamic determines the region's high readiness for digitalization. The hierarchical nature of forming the priorities and parameters of digitalization of the region's electric power infrastructure was defined. The analysis was done of the digital environment for developing the electric power spatial infrastructure system of the region based on the national, regional, and corporate level documents, which allowed determining the general targets for digitalization - implementing digital technologies for reliable and accessible electricity supply.
\end{abstract}

\section{Introduction}

At the present stage, the socio-economic development of the regions and its level are closely related to the state of development of information technologies [1-4]. In the world ranking of digital competitiveness in 2019, Russia's position was 38th out of 63. In 2019, Russia's domestic expenditures on the development of digital economy from all the sources amounted to $2.1 \%$ as a percentage of GDP and the gross added value of the ICT sector as a percentage of GDP was $2.81 \%$ [5].

The development of digital economy aims both to solve the specific problems of economic activity for increasing the efficiency of the production processes as well as the relationships between the subjects, accelerating the business processes, and to increase the competitiveness of the economy in international markets.

The works of many domestic and foreign scientists are devoted to the study of various aspects of the digital economy formation and digitalization. Within the study, special interest was shown to the works, which analyze the impact of digitalization on the development of the regional economy and its components in the aspect of reindustrialization and sustainable

\footnotetext{
*Corresponding author: shishea@usue.ru
} 
development. In this regard, it is necessary to highlight the works of many prominent scientists [6-10].

The electric power spatial infrastructure system of the region is the key element in forming the digital energy production based on the new technological paradigm, which is defined in the strategic documents [11].

The purpose of the study is to analyze the formation of the digital environment for developing the electric power spatial infrastructure system in the region. The research area was the Sverdlovsk region and its electric power spatial infrastructure system. The logic of the research provides for solving the following tasks: first, determining the hierarchical levels of forming the digital environment to develop the spatial infrastructure systems in the region; second, analyzing and evaluating the priorities, the parameters of forming the digital environment to develop the spatial infrastructure system in the region, seeing the balance between them.

\section{Materials and methods}

The formation of the digital economy in the Russian Federation as a priority direction of development and the condition for increasing the economic efficiency based on the introduction of information technologies, systems and services was given a start relatively recently. In 2016 V. V. Putin addressed his message to the Federal Assembly of the Russian Federation. Since then, the formation of the digital environment for the development of the national and regional economy has begun, which reflected in the adoption and implementation of a number of strategic documents, among which special importance is given to the Program "Digital Economy of the Russian Federation" (approved by the Decree of the Government of the Russian Federation of July 28, 2017, No 1632-r). The strategic goal of the digital economy development at the national and regional levels is "the transition to the economy of a new technological generation, the "digital economy" based on the creation of a sustainable and secure information and telecommunications infrastructure". This determines the vector of development of both the regions and the objects in tem including the infrastructure systems

The development of spatial infrastructure systems and the development of the economic space of the region are interconnected and interdependent processes. Ensuring sustainable development is largely connected with the functioning of the electric power spatial infrastructure system in the region, it depends on the state of this system, its supplying, networking and connecting functions. The processes of neo-industrial development and digitalization cause a change in the role of the electric power spatial infrastructure system of the region plays in the economic space. Digitalization of spatial infrastructure systems is determined in departmental documents. The departmental project "Digital Energy" [12] aims to develop the energy production infrastructure of the Russian Federation by implementing digital technologies and platform solutions through digital services and solutions development. At the corporate level, the direction of digitalization of the electric power spatial infrastructure system of the Russian Federation is determined by the Concept of Digital Transformation 2030 of "Rosseti" PJSC [13], according to which the digital transformation of the networks is based on digital technologies and big data analysis. Thus, at the federal level, the formation of a digital environment for developing an electric power spatial infrastructure system is determined by national, departmental and corporate documents, agreed upon concerning the targets. 


\section{Empirical model}

In terms of regional development, the goal of digitalization is to transform the objects of the regional economy and social sphere based on accelerated implementation of domestic digital technologies and platform solutions [15]. The Sverdlovsk region shows high readiness for digitalization in both ICT and non-ICT industries (Table 1,2).

Table 1. Analysis of the dynamics of the use of information and communication technologies by organizations of the Sverdlovsk region (excluding small businesses), in\% compared to the previous period [14]

\begin{tabular}{|l|l|l|l|l|r|}
\hline \multicolumn{1}{|c|}{ Indicators } & 2016 & 2017 & 2018 & 2019 & $\begin{array}{c}\text { Growth } \\
\text { rate for } \\
\text { the } \\
\text { period, } \%\end{array}$ \\
\hline $\begin{array}{c}\text { Organizations' expenditures on } \\
\text { information and communication } \\
\text { technologies, mln RUB. }\end{array}$ & 72,6 & 125,5 & 105,7 & 108,5 & 149,4 \\
\hline $\begin{array}{l}\text { Number of organizations belonging to } \\
\text { the ICT sector, units. }\end{array}$ & 127,5 & 98,5 & 113,5 & 91,3 & 71,6 \\
\hline $\begin{array}{c}\text { Headcount in organizations belonging to } \\
\text { the ICT sector, thousand people. }\end{array}$ & 99,3 & 57,9 & 108,8 & 104,1 & 104,8 \\
\hline $\begin{array}{c}\text { Shipped own-production goods and } \\
\text { services related to information and } \\
\text { communication technologies, mln RUB }\end{array}$ & 94,3 & 93,4 & 108,7 & 116,7 & 123,8 \\
\hline
\end{tabular}

For the period of 2016-2019 organizations' expenditures on information and communication technologies increased by $49.4 \%$ (growth rate 149.4\%), since 2018 the indicator has been increasing annually. There is also a $23.8 \%$ increase in shipped goods and services) of own production related to information and communication technologies. The number of employees on the payroll in ICT-related organizations increased by $4.8 \%$ compared to 2016 . At the same time, the number of organizations belonging to the ICT sector decreased by $29.4 \%$.

Table 2. The proportion of organizations in the Sverdlovsk region that used global information networks (as a percentage of the total number of surveyed organizations of the respective type of economic activity) [14]

\begin{tabular}{|c|c|c|c|c|c|c|c|c|c|}
\hline & \multicolumn{6}{|c|}{ Organizations using } & \multicolumn{3}{c|}{$\begin{array}{c}\text { Organizations having a } \\
\text { website }\end{array}$} \\
\cline { 2 - 10 } & \multicolumn{3}{|c|}{$\begin{array}{c}\text { Global information } \\
\text { networks }\end{array}$} & \multicolumn{3}{c|}{$\begin{array}{c}\text { Including using the } \\
\text { Internet }\end{array}$} & \multicolumn{4}{c|}{} \\
\cline { 2 - 9 } & 2017 & 2018 & 2019 & 2017 & 2018 & 2019 & 2017 & 2018 & 2019 \\
\hline Total & 89,7 & 92,0 & 92,0 & 88,9 & 91,1 & 91,2 & 47,4 & 50,9 & 51,9 \\
\hline $\begin{array}{l}\text { Supply of } \\
\text { electricity, } \\
\text { gas and } \\
\text { steam; air } \\
\text { conditioning }\end{array}$ & 92,3 & 91,5 & 93,5 & 89,6 & 89,1 & 92,5 & 47,5 & 47,7 & 51,1 \\
\hline
\end{tabular}

In 2017-2019 the dynamics of the share of organizations using global information networks in the type of activity "Supply of electricity, gas and steam ; air conditioning" 
generally corresponds to the dynamics of the total number of organizations. During the study period, more than $89.0 \%$ of the total number of organizations and more than $91.5 \%$ by the type of activity used global information networks. In $2017-2019$ more than $47.0 \%$ of the total number and more than $47.5 \%$ of organizations by the type of activity had a website.

As part of implementing the national program "Digital Economy of the Russian Federation" at the regional level in the Sverdlovsk region, the following regional projects are being implemented "Information Infrastructure", "Personnel for the Digital Economy", "Information Security", "Digital Technologies", "Digital Public Administration", the regional program for the development of the digital economy [16]. In accordance with the national program "Digital Economy" and the departmental project of the Ministry of Construction, Housing and Utilities of the Russian Federation on digitalization of the urban economy "Smart City", the passport of the regional program "Smart Cities of the Sverdlovsk region" (hereinafter referred to as the "Smart City" program) was formed, which also includes a list of projects and a number of activities for the implementation of digital platform solutions and smart services

The "Smart City" program includes the following projects: city management; smart housing and utilities; innovations for the urban environment; smart city transport; intelligent public security systems; communication network infrastructure. The projects contain a number of objectives and measures to implement digital platform solutions and smart services. In 2019, the Government of the Sverdlovsk region received an appeal from Smart Light Solutions LLC regarding the implementation of the Smart City program projects in the Sverdlovsk Region using public-private and municipal-private partnership mechanisms involving concession and energy service instruments, as well as the possibility of investing about 10 billion rubles. One of the key tasks of the "Smart City" standard is implementing the "Energy Efficient Smart City Lighting" service (section "Innovations for the Urban Environment").

In 2018, in Ekaterinburg, to promote the Agreement between the Government of the Sverdlovsk region and the "ER-Telecom Holding" company of July 10, 2018 No. 46, the first Internet of Things (IoT) network based on the LPWAN standard was launched, which can be the basis for implementing the "Smart City" projects at a modern level.

Thus, in the region, work is underway to introduce an energy efficient intelligent urban lighting system in the city of Yekaterinburg using the existing urban Internet of Things (IoT) network, the investor of which is "ER-Telecom Holding" JSC.

The owners of the infrastructure - the corporate sector is also developing and implementing programs for digitalization of the regional spatial infrastructure systems. The development of the electric grid infrastructure of the region is carried out as part of the activities of OAO "IDGC of Urals". The Board of Directors of the Company (Minutes of 28.04.2017 No. 224) approved the Program of Innovative Development of OAO "IDGC of Urals" for the period 2016-2020. with a perspective up to 2025.

The main directions of innovative development are new technologies and solutions, digitalization of management and technological processes. In accordance with the Executive Orders of the President of the Russian Federation "On the 2017-2030 Strategy for the Development of an Information Society in the Russian Federation " of 09.05.2017 No 203, "On National Goals and Strategic Objectives of the Development of the Russian Federation through to 2024" of 07.05.2018 No 204, Orders of the Government of the Russian Federation of July 28, 2017 No 1632r to implement the Concept of PJSC ROSSETI "Digital Transformation - 2030", approved by the Board of Directors of PJSC "ROSSETI" (Minutes of the meeting of 21.12.2018 No 336), it is assumed that the main principles and development directions of the power grid complex of OAO "IDGC of Urals" will be reconsidered.

At the moment, the program "Digital Transformation of OAO "IDGC of Urals" for 20202030" has been adopted and approved, the purpose of which is "to change the logic of the 
processes and the transition of the company to risk-oriented management based on digital technologies and of big data analysis" [17] The program contains pilot projects for the digital transformation of the power grid company in the territory of its presence, aimed at improving the quality of power supply to consumers by reducing power losses, increasing the observability and controllability of distribution networks. An integral part of the company's digital transformation program is the Program for the Development of Smart Metering of Electricity in the Company's Power Grids for 2020-2030. The development of the company is also carried out within the agreements with the Government of the Sverdlovsk region on innovative development of the power grid complex. The total costs of the implementation of the digital transformation program will amount to 53 billion rubles, the sources of which are the company's own and borrowed funds.

\section{Results and discussions}

To summarize the results of the study on the digital environment for the development of the electric power spatial infrastructure system in the region, the levels and target priorities should be highlighted (Table 3).

Table 3. The levels of forming the digital environment to develop the electric power space infrastructure system in the region

\begin{tabular}{|c|c|c|}
\hline Level & Document & Targets \\
\hline Federal & $\begin{array}{l}\text { Program "Digital Economy of the Russian } \\
\text { Federation" (approved by the Government } \\
\text { of the Russian Federation of July 28, } 2017 \\
\text { No. 1632-r); Departmental project " Digital } \\
\text { Energy", Package plan for modernization } \\
\text { and expansion of the main infrastructure for } \\
\text { the period to } 2024 \text { (Decree of the } \\
\text { Government of the Russian Federation of } \\
\text { September 30, } 2018 \text { N } 2101-r \text {, amended on } \\
\text { March 13, 2020); program "Digital } \\
\text { Transformation of the Russian Electric } \\
\text { Power Industry"; concept of digital } \\
\text { transformation } 2030 \text { of PJSC "ROSSETI"; } \\
\text { "On National Goals and Strategic Objectives } \\
\text { of the Development of the Russian } \\
\text { Federation through to 2024" (Executive } \\
\text { Order of the President of the Russian } \\
\text { Federation No. } 204 \text { of } 07.05 .2018 \text { ) }\end{array}$ & $\begin{array}{l}\text { Increasing the availability and } \\
\text { quality of goods and services } \\
\text { produced in the digital economy } \\
\text { using modern digital } \\
\text { technologies; introduction of } \\
\text { digital technologies in the } \\
\text { energy sector, transition to } \\
\text { intelligent energy, demand } \\
\text { management and price- } \\
\text { dependent consumption } \\
\text { reduction, } \\
\text { transformation of the Russian } \\
\text { energy infrastructure through } \\
\text { the introduction of digital } \\
\text { technologies and platform } \\
\text { solutions to improve its } \\
\text { efficiency and safety }\end{array}$ \\
\hline Regional & $\begin{array}{l}\text { Regional projects of the Sverdlovsk region: } \\
\text { "Information Infrastructure", "Personnel for } \\
\text { the Digital Economy", "Information } \\
\text { Security", "Digital Technologies", "Digital } \\
\text { Public Administration", "Smart Region" } \\
\text { concept }\end{array}$ & $\begin{array}{l}\text { Systemic implementation of } \\
\text { information services and } \\
\text { solutions based on the latest } \\
\text { achievements in the field of } \\
\text { digital technologies for the } \\
\text { development of human capital, } \\
\text { improving the quality of life and } \\
\text { increasing the competitiveness } \\
\text { of the economy }\end{array}$ \\
\hline Corporate & $\begin{array}{l}\text { Concept "Digital transformation of PJSC } \\
\text { "ROSSETI" 2030" (approved by the Board } \\
\text { of Directors of PJSC "ROSSETI", minutes } \\
\text { of December 21, 2018) No. 336; The } \\
\text { program of innovative development of OAO }\end{array}$ & $\begin{array}{l}\text { Changing the logic of the } \\
\text { processes and transition of the } \\
\text { company to risk-oriented } \\
\text { management by introduction of }\end{array}$ \\
\hline
\end{tabular}




\begin{tabular}{|l|l|l|}
\hline & $\begin{array}{l}\text { "IDGC of Urals" for 2016-2020 with a } \\
\text { prospect until 2025 (approved by the Board } \\
\text { of Directors of the Company, minutes of }\end{array}$ & $\begin{array}{l}\text { digital technologies and big data } \\
\text { analysis }\end{array}$ \\
$\begin{array}{l}\text { 28.04.2017 No. 224); program "Digital } \\
\text { Transformation of OAO "IDGC of Urals" } \\
\text { for 2020-2030". }\end{array}$ & \\
\hline
\end{tabular}

Thus, the formation of a digital environment for the development of the electric power spatial infrastructure system of the region is represented by several levels: federal, regional, corporate. At each level, a system of documents has been formed that defines the goals and objectives of digitalization. Content analysis of the documents in Table 3 shows that the general target is to use digital technologies for reliable and accessible [18] electricity supply. At the same time, particular tasks are determined for introducing digital technologies into business processes and public administration. However, the documents are not fully interrelated, there is discrepancy in timescales, priorities and planning parameters, which complicates the process of strategic planning and achieving the goals set.

\section{Conclusions}

The study of the formation of a digital environment for forming spatial infrastructure systems in the region (the case of the electric power industry) allows drawing the following conclusions:

- the region has a digital environment for developing the electric power spatial infrastructure system, which is reflected by federal, regional, corporate documents both complex and by type of activity. However, there is not enough interconnection and balance between them.

- there is hierarchical order of developing the priorities and parameters of digitalization of electric power infrastructure;

- the target parameters of digitalization in the electric power spatial infrastructure system are increased reliability and accessibility for the public and business, effective electricity supply for the regional development;

- there are potential risks of a technological and macroeconomic nature, different understanding of digitalization in the industry companies due to inequality, differences in the access to the use of technologies;

- mechanisms are not defined to coordinate the tasks and digitalization results in horizontal and vertical management.

\section{References}

1. I.L. Avdeeva, T.A. Golovina, L.V. Parakhina. Management issues, 6 (49) (2017)

2. A.N. Kozyrev, http://digital-economy.ru/ (2021)

3. N.M. Surnina, E.A. Shishkina, Journal of New Economy, 5 (61), 69 (2015)

4. V.G. Khalin, G.V. Chernova, Administrative Consulting, (10), 46 (2018)

5. G. Abdrakhmanova, K. Vishnevskiy, L. Gokhberg et al. Digital Economy Indicators in the Russian Federation (2020)

6. A.I. Tatarkin, V.V. Akberdina, N.Yu. Buhvalov, Proceedings of $2^{\text {nd }}$ International conference: Strategies for Developing Social Groups, Institutes, and Territories, 41 (2016)

7. E.A. Istomina, Bulletin of Chelyabinsk State University. Economic sciences, 12 (422), 108 (2018) 
8. N.M. Surnina, E.A. Shishkina, Scientific Publications of the Free Economic Society of Russia, 3 (223), 251 (2020)

9. L.V. Lapidus, L.S. Leontieva, A.O. Gostilovich, Public administration (E-Journal), 77, 212 (2019)

10. V.V. Akberdina, Journal of New Economy, 19 (3), 82 (2018)

11. N.D. Rogalev, Digital energy: a new paradigm of functioning and development, 300 (2019)

12. Departmental project «Digital Energy», https://minenergo.gov.ru/

13. Digital transformation 2030 concept, PJSC ROSSETI, 2018

14. Science, innovation, and the Information Society, Federal State Statistic Service, https://sverdl.gks.ru/folder/30403 (2021)

15. ANO "Digital economy", https://data-economy.ru/ (2021)

16. Digital economy of the Sverdlovsk oblast', https://cвe.pp/ (2021)

17. 2020-2030 Digital Transformation of OAO IDGC of Urals Program, https://www.mrskural.ru/ (2021)

18. A. Dyachkov, N. Surnina, E. Shishkina, Proceedings of the International Scientific Conference on Competitive, Sustainable and Secure Development of the Regional Economy: Re-sponse to Global Challenges (CSSDRE 2018), Advances in Economics, Business and Management Research, 39, 485 (2018) 